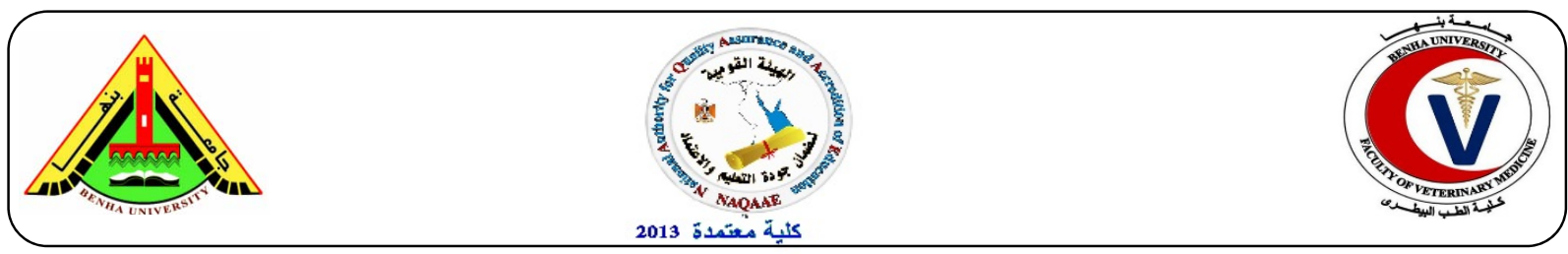

\title{
Evaluation of the antiviral effect of bee venom on rabies virus
}

\author{
${ }^{1}$ Eiaka, A.M.; ${ }^{2}$ El-Bagoury, G.F. ${ }^{2}$ El-Nahas, E.M. and ${ }^{3}$ Khodeir, M.H. \\ ${ }^{1}$ Sera Plant, VACSERA \\ ${ }^{2}$ Faculty of Veterinary Medicine, Benha University \\ ${ }^{3}$ Veterinary Serum and Vaccine Research Institute, Abassia, Cairo
}

\section{A B S T R A C T}

It is an interesting thing to known the effect of natural matter as bee venom as antiviral agent and to any extent it could be used in case of experimental rabies infection. In vitro study revealed that different concentrations of bee venom (started from the original concentration " $1 \mathrm{mg} / \mathrm{ml}$ " up to 1:1000) did not show any cell growth retarders or cellular changes showing normal growth rate and normal cell shape. $1 \mathrm{mg} / \mathrm{ml}$ and $100 \mu \mathrm{gm} / \mathrm{ml}$ of bee venom were able to inhibit the replication of $100 \mathrm{TCID}_{50}$ of rabies virus (ERA strain) in using baby hamster kidney BHK cells while 10 and $1 \mu \mathrm{gm} / \mathrm{ml}$ were negative. In vivo study showed that mice received rabies immune globulin and BV were able to withstand the rabis infection when the they were administrated on the $0,1^{\text {st }}, 2^{\text {nd }}$ and $3^{\text {rd }}$ day post infection showing protection rate of 90 and $80 \%$ respectively but those mice received the treatment on the following days did not survive the infection and showed paralysis of the hind limbs by the $4^{\text {th }}$ day and died by the $6-7^{\text {th }}$ day post infection. It could be concluded that bee venom could be used in case of rabies infection when administrated on the suitable time post exposure.

Key word: Antiviral, Bee Venom, Rabies Virus.

\section{INTRODUCTION}

Rabies is an acute viral disease of the nervous system of warm-blooded animals that is caused by a rhabdo virus (species Rabies virus of the genus Lyssa virus)(National Centre for Disease Control, 2014).The disease transmitted by infected saliva usually through the bite of rabid animal as well as scratches and that is characterized typically by increased salivation, abnormal behavior, and eventual paralysis and death of untreated cases (WHO, 2014).The disease is almost fatal following the onset of clinical signs. The disease is preventable by timely administration of post exposure prophylaxis (PEP) consisting of four or five doses of rabies vaccine combined, in the most severe cases of exposures, with anti-rabies immunoglobulin (RIG). PEP consists of a multimodal approach to decrease an individual's likelihood of developing clinical rabies after a possible exposure to the virus. Every year, approximately 55000 individuals worldwide die due to rabies infection (Bourhy et al., 2009). A study of one year follow-up enrolled 193 patients; aged 16 months to 79 years; received post exposure prophylaxis (PEP) encompasses wound cleaning; infiltration of rabies immunoglobulin (RIG) and rabies vaccination following exposure to baiting of rabid animals. Where serious adverse events were considered related to PEP recommended that PEP treatment is highly effective where 191 (99\%) patients were in good health one year post exposure (Quiambao et al., 2009). Nowadays there is an attention toward the use of natural antiviral agent to overcome serious viral diseases. Bee venom is a complex mixture of proteins, peptides and low molecular component. The main components are proteins and peptides. BV has numerous polypeptides the main one being melittin (Shkenderov and Ivanov, 1983) in addition contains several biochemical or pharmacologically active substances, including antibacterial, antiparasitic and antiviral properties (Guillaume et al., 2006). The viricidal activity (direct action) of bee venom on Herpes simplex virus type-1(HSV1) and Adenovirus type -7(adeno-7) as a DNA virus models studies revealed there was a significant depletion rate of virus infectivity titer 6 and $24 \mathrm{hrs}$. post treatment recording $3.7 \mathrm{log}$ (10)/0.1 ml and $2.75 \log (10) / 0.1 \mathrm{ml}$ respectively. Also, the evaluation of viricidal activity of bee venom against RNA model virus of West Nile virus (WNV) revealed that there was a significant decreased in WNV infectivity titer post thermal treatment incubation at $37 \mathrm{oC}$ for 3 , 6 , and 24 and 48 hours post treatment with venom 
recording $5.1 \log (10) / 0.1 \mathrm{ml}, 4.5 \log (10) / 0.1$ $\mathrm{ml}, 2.1 \log (10) / 0.1 \mathrm{ml}$ and $0.55 \log (10) / 0.1 \mathrm{ml}$ respectively (Rawhia et al., 2009). The evaluation of veridical activity of bee venom against RNA model virus of West Nile virus (WNV) revealed that there was significant decrease in Adeno virus titer 3,6 and 24 hours post incubation at $37^{\circ} \mathrm{C}$ with BV was noticed (Jason, 2013). Also, evaluation of the antiviral activity of bee venom against RNA model virus WNV revealed that there was a nonsignificant decrease in West Nile Virus titer after incubation period of 3, 6 and 24 hours' post treatment at $37^{\circ} \mathrm{C}$. Melittin can poke holes in the protective viral envelope that surrounds the human immunodeficiency virus, as well as other viruses (Hood et al., 2013). Hassan et al. (2015) used two different virus models namely Adeno-7 as DNA model and RVFV as RNA virus models to investigate the antiviral effect of BV. The depletion of viral infectivity titer of $\mathrm{ABW}$ to Adeno-7 virus showed strong antiviral activity recorded a depletion of viral infectivity titer (1.66 log (10)/ $\mathrm{ml})$ that gave equal action with BV and more than interferon IFN (1 log (10)/ ml).

The present study aims to spot the light on bee venom as antiviral in rabies infection as recent directions toward the use of antiviral components in trials for protection or treatment of viral diseases.

\section{MATERIALS AND METHODS}

\subsection{Bee venom:}

Honey BV was supplied by Sera plant, The Holding Company for Biological Products and Vaccines (VACSERA). It was obtained at a concentration of $1 \mathrm{mg} / \mathrm{ml}$ saline

\subsection{Challenge virus strain (CVS):}

CVS mice brain adapted rabies virus with a titer of $10^{6} \mathrm{MLID}_{50} / \mathrm{ml}$ was supplied by DPAVR and used for the induction of experimental rabies infection in mice.

\subsection{Rabies immune-globulin:}

It was prepared by Albehwar (2009) and supplied kindly by the DPAVR and used in a comparative evaluation with bee venom as antiviral substances.

\subsection{Safety assay of honey bee venom:}

\subsubsection{In vetro safety assay:}

The safety of bee venom was tested in cultivation monolayer of Baby hamster kidney BHK cell culture through determination of its cytotoxic effect where serial tenfold dilutions of the venom were prepared in Hankes balance salt solution HBSS and $25 \mu 1$ of each dilution were inoculated in each of 5 wells of 96 wells tissue culture plates. Normal cell culture wells were included as test control. The cell culture plates were incubated at $37^{\circ} \mathrm{C}$ and subjected for daily microscopic examination for determination of any cell abnormalities up to 7 days.

\subsubsection{In vivo safety assay:}

Ten fold dilutions of bee venom were prepared in normal saline $7.2 \mathrm{pH}$ started from the original material up to $10^{3}$ where each dilution was inoculated intraperitonially in ten mice using a dose of $0.5 \mathrm{ml} / \mathrm{mouse}$. Ten mice were kept without inoculation as test control. All mice were kept under observation up to 15 days post inoculation

\subsection{Investigation of the antiviral effect of bee venom:}

\subsubsection{Invitro antiviral assay:}

BHK cultured plates were infected with rabies virus using $25 \mu \mathrm{l} /$ well of $100 \mathrm{TCID}_{50}$ of the used virus. After one hour allowed for virus adsorption, the cells were washed twice with phosphate buffer saline PBS then each one of the prepared bee venom concentrations (undiluted up to 1 i.e. from $1 \mathrm{mg}$ to $10 \mu \mathrm{g} / \mathrm{ml}$ ) was added to each of 5 tissue culture wells with $150 \mu 1$ of maintenance medium. The test included normal cells and untreated virus controls. All plates were subjected to daily microscopic examination.

\subsubsection{In vivo antiviral assay:}

Four hundred albino Swiss mice were divided into 6 groups as follows: Group 1 and 2 each of 100 mice were experimentally infected with the CVS through the intra-cerebral route using 0.03 $\mathrm{ml} /$ mouse according to Seligmann (1973). Group1 was subdivided into 10 subgroups which were treated with $\mathrm{BV}$ inoculated $\mathrm{I} / \mathrm{P}$ using a dose of $50 \mu \mathrm{gm} /$ mouse on the $0,1,2,3,4,5,6,7,8,9$ and 10 days' post infection. Group-2 was subdivided into 10 subgroups (10 mice/subgroup) treated with rabies immunoglobulin (342mg/mouse) according to Albehwar (2009) inoculated I/P on the same periods post infection. Groups 3-6 (each contains 50 mice) were treated as follow: Group3 was kept infected with the CVS without treatment. Group-4 was inoculated I/P with rabies immunoglobulin alone. Group-5 was inoculated I/P with BV alone. Group-6 was kept without infection and without treatment as normal control. All mice were kept under hygienic measures receiving balanced ration and adequate water and subjected to daily observation. 


\section{RESULTS}

\subsection{In vitro testing the safety and antiviral effect of bee venom:}

Inoculation of different concentrations of BV (started from the original concentration " $1 \mathrm{mg} / \mathrm{ml}$ " up to 1:1000) did not show any cell growth retarders or cellular changes where normal growth rate and normal cell shape. It was found that $1 \mathrm{mg} / \mathrm{ml}$ and $100 \mu \mathrm{gm} / \mathrm{ml}$ of bee venom were able to inhibit the replication of 100 TCID $_{50}$ of rabies virus (ERA strain) in BHK cells while 10 and $1 \mu \mathrm{gm} / \mathrm{ml}$ were unable to prevent or reduce the virus replication showing clear specific $\mathrm{CPE}$ as demonstrated in table (1)

\subsection{In vivo safety and antiviral effect of $B V$ :}

It was found that mice received rabies immune globulin and BV were able to withstand the infection when the they were administrated on the $\mathrm{o}, 1^{\text {st }}, 2^{\text {nd }}$ and $3^{\text {rd }}$ day post infection showing protection rate of 90 and $80 \%$ respectively but those mice received the treatment on the following days did not survive the infection and showed paralysis of the hind limbs by the $4^{\text {th }}$ day and died by the $6-7^{\text {th }}$ day post infection as demonstrated in table (2).

Table (1): In vitro safety and antiviral activity of bee venom in BHK cell culture

\begin{tabular}{lll}
\hline $\begin{array}{l}\text { Tested concentration of bee } \\
\text { venom }\end{array}$ & $\begin{array}{l}\text { Determined changes in BHK } \\
\text { Cell culture }\end{array}$ & $\begin{array}{l}\text { Antiviral activity of bee venom } \\
\text { against 100TCID }\end{array}$ of rabies virus \\
\hline Undiluted $(1 \mathrm{mg} / \mathrm{ml})$ & There were neither cell changes nor growth & $\begin{array}{l}\text { Inhibited virus replication showing no } \\
\text { CPE }\end{array}$ \\
$1: 10(100 \mu \mathrm{gm} / \mathrm{ml})$ & Did not affect virus replication \\
$1: 100(10 \mu \mathrm{gm} / \mathrm{ml})$ & inhibition & showing clear specific CPE \\
$1: 1000(1 \mu \mathrm{gm} / \mathrm{ml})$ & & \\
\hline
\end{tabular}

Table (2): In vivo safety and antiviral effect of bee venom

\begin{tabular}{|c|c|c|c|c|c|c|c|c|}
\hline \multirow{2}{*}{$\begin{array}{l}\text { Inoculated } \\
\text { Material }\end{array}$} & \multicolumn{8}{|c|}{ Number of survived mice/number of treated infected mice $=$ protection $\%$} \\
\hline & 1DPI* & 2DPI & 3DPI & 4DPI & 5DPI & 6DPI & 7DPI & 8DPi \\
\hline $\begin{array}{l}\text { Rabies } \quad \text { IgG } \\
(342 \mathrm{mg} / \mathrm{mouse})\end{array}$ & 100 & 100 & 90 & 40 & 10 & 0 & 0 & 0 \\
\hline $\begin{array}{l}\text { BV } \\
(50 \mu \mathrm{gm} / \mathrm{mouse})\end{array}$ & 100 & 100 & 80 & 30 & 3 & 0 & 0 & 0 \\
\hline Infected control & \multicolumn{8}{|c|}{$\begin{array}{l}\text { Began to show typical rabies symptoms by the } 4^{\text {th }} \text { day post infection and death by the } \\
6 \text { to } 7 \text { days later }\end{array}$} \\
\hline $\begin{array}{l}\text { Normal control } \\
\text { Immune globulin } \\
\text { control } \\
\text { BV control }\end{array}$ & \multicolumn{8}{|c|}{$\begin{array}{l}\text { Remain healthy all over the experimental period showing neither local or general } \\
\text { abnormalities }\end{array}$} \\
\hline
\end{tabular}

\section{DISCUSSION}

The development of antiviral drugs is still in its infancy with rapid changes and progressive milestones encountered almost daily. The last two decades have been the most dynamic in the history of viral infections and their management. Unfortunately, antiviral drugs have been effective for only a few groups of viruses until now. Most antiviral drugs do not produce a cure, but rather allow control of the infection. However, the limitations of antiviral therapy, including the high costs of drugs, make the need for prevention even more urgent (Trying, 2005).
In vitro investigation of the effect of different concentrations of BV did not show any cell retarded growth or cellular changes. On the other side, it was found that $1 \mathrm{mg} / \mathrm{ml}$ and $100 \mu \mathrm{gm} / \mathrm{ml}$ of bee venom were able to inhibit the replication of $100 \mathrm{TCID}_{50}$ of rabies virus (ERA strain) in BHK cells while 10 and $1 \mu \mathrm{gm} / \mathrm{ml}$ were unable to do this showing clear specific CPE as demonstrated in table (1). In this respect Rawhia et al. (2009) reported that evaluation of viricidal activity of bee venom against RNA model virus of West Nile virus (WNV) revealed that there was a significant decreased in WNV infectivity titer post incubation at $37^{\circ} \mathrm{C}$ for 3,6 , and 24 and 48hours post treatment with venom recording 5.1 
$\log (10) / 0.1 \mathrm{ml}, 4.5 \log (10) / 0.1 \mathrm{ml}, 2.1 \log (10) / 0.1$ $\mathrm{ml}$ and $0.55 \log (10) / 0.1 \mathrm{ml}$ respectively. The RNA model virus; WNV was well influenced by bee venom than IFN where the virus infectivity titer recorded $1 \log (10) / 0.1 \mathrm{ml}$ post $\mathrm{BV}$ treatment compared with $2.5 \log (10) / 0.1 \mathrm{ml}$ virus infectivity titer post IFN treatment. Also Hassan et al. (2015) used two different virus models Adeno-7 model and RVFV as RNA virus models to determine the antiviral effect of BV. They found that the depletion of viral infectivity showed strong antiviral activity recorded a depletion of viral infectivity titer $(1.66 \log (10) / \mathrm{ml})$ that gave equal action with bee venom and more than interferon IFN $(1 \log (10) / \mathrm{ml})$.

Parallel to the results of in vitro studies, the in vivo investigation of $B V$ anti-viral effect revealed that mice received rabies immune globulin and BV were able to withstand the infection when the they were administrated on the $0,1^{\text {st }}, 2^{\text {nd }}$ and $3^{\text {rd }}$ day post infection showing protection rate of 90 and $80 \%$ respectively while treatment on the following days did not overcome the infection showing paralysis of the hind limbs by the $4^{\text {th }}$ day and death by the 6$7^{\text {th }}$ day post infection as demonstrated in table (2) and photo (3). These observations indicate that post exposure treatment against rabies should be as soon as possible and the late administration leads to fast disease arise. There were no available data that discuss emergency immunization of animals against rabies but Barnas (2001) stated that rabies immune globulin could be applied for animals. In addition Khodeir and Daoud (2008) found that passive immunization of experimentally infected mice showed that these mice were able to withstand the infection when treated with the antiserum on the $1^{\text {st }}, 2^{\text {nd }}$ and $3^{\text {rd }}$ day post infection but cannot survive after that. Also, Albehwar (2009) advised that post exposure immunization of animals should be carried out as soon as possible on time post exposure and recommended the same periods. either homologous or heterologous species anti-rabies sera could be used safely in emergency cases. In addition, Hood et al. (2013) stated that the toxin found in bee venom Melittin destroys some viruses which can poke holes in the protective viral envelope that surrounds the viruses. Joshua and Hood (2015) suggested that this action is possible where melittin attacks the membranes of the virus.

This work indicates the inoculation of mice with $\mathrm{BV}$ as anti-rabies virus was sufficient to possibility to use rabies immune globulin or bee venom in emergency cases of rabies exposure administrated on the suitable time post exposure in other species.

\section{REFERENCES}

Albehwar, A.M.A. 2009. Studies on prophylactic and emergency vaccination of farm animals against rabiesPh.D., Cairo Univ.

Barnas, G.P., 2001. Rabies vaccinationWHO position. weekly epidemiological record 77, 109-120

Bourhy, H., Goudal, M., Mailles, A., Sadkowska-Todys, M., Dacheux, L., Zeller, H., 2009. Is there a need for anti-rabies vaccine and immunoglobulins rationing in Europe? Euro Surveill 1419166.

Guillaume, C., Calzada, C., Lagarde, M., Schrevel, J., Deregnaucourt, C., 2006. Interplay between lipoproteins and bee venom phospholipase A2in relationto theiranti-plasmodium toxicity. J. Lipid . Res. 47, 1493.

Hassan, M.I., Mohamed, A.F., Amer, M.A., Hammad, K.M., Riad, S.A., 2015. Monitoring of the antiviral potential of bee venom and wax extracts against Adeno-7 (DNA) and Rift Valley fever virus (RNA) viruses models J Egypt Soc Parasitol. 45, 193-198.

Hood, J.L., Jallouck, A.P., Campbell, N., Ratner, L., Wickline, S.A., 2013. Cytolytic nanoparticles attenuate HIV-1 infectivity. 19, $95-103$.

Jason, K.M., 2013. Bee venom, a traditional medical treatment in some parts of the world, may become crucial to halting the HIV/AIDS pandemic.

Joshua, L., Hood, M.D. 2015. Nanoparticles containing bee venom toxin melittin can destroy human immunodeficiency virus (HIV) while at the same time leaving surrounding cells unharmedPhD.

Khodeir, M.H., Daoud, A.M., 2008. Preparation of antirabies hyperimmune serum for emergency immunization of farm animals. 4 th Int. Sci. Conf. NRC, 1-9

Quiambao, B.P., Dy-Tioco, H.Z., Dizon, R.M., Crisostomo, M.E., Teuwen, D.E., 2009. Rabies post-exposure prophylaxis with purified equine rabies immunoglobulin: one-year follow-up of patients with laboratory-confirmed category III rabies exposure in the Philippines. Vaccine 27, $7162-7166$.

Rawhia, H.R., Aly, F.M., Mohamed, S.A.E.-D., 2009. Evaluation of antiviral activity of honeybee venom on DNA and RNA virus models. Acad. J. Biolog. Sci.1, 21, 247- 258.

Seligmann, B., 1973. The NIH test for potency, Laboratory Techniques in rabies3rd Ed. WHO monograph series. 33, 279.

Shkenderov, S., Ivanov, T., 1983. The Bee Products (in Bulgarian) Zemizdat 1, 238.

Trying, S.K., 2005. Antiviral agents; vaccines and immunotherapies (Preface).

WHO, 2014. Rabies Fact Sheet ${ }^{\circ} 99$. 